\title{
Homenagem a Brasilmar Ferreira Nunes
}

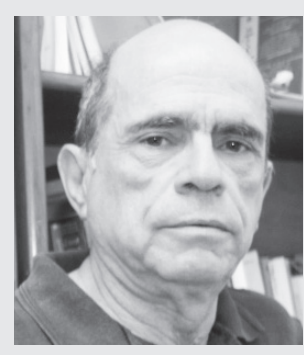

To dia 18 de abril, 1 faleceu, em Brasília, o sociólogo Brasilmar Ferreira Nunes. Anpuriano de coração, ele deixou suas marcas ao participar da diretoria da ANPUR em duas ocasióes (2003-2005 e 2007-2009), além de ter integrado um dos júris de tese de doutorado e o corpo de pareceristas da Revista Brasileira de Estudos Urbanos e Regionais - RBEUR.

Brasilmar era admirável. Situava-se entre aquelas pessoas portadoras de uma intensa alegria, generosidade e sinceridade. Buscava ensinar a seus alunos o mais alto valor ético: a solidariedade humana. Fazia isso por meio de debates acadêmicos. Era partidário da ideia de uma sociedade mais justa e democrática. Era, portanto, alguém de esquerda, no sentido conferido por Deleuze a esse termo. Para esse filósofo francês, ser de esquerda ou de direita trata-se de uma questão de percepção. Enquanto o indivíduo de direita percebe o mundo a partir de si mesmo, da sua família, da sua rua, dos seus interesses, quem é de esquerda olha o horizonte, sabendo que ele, tal como está hoje, não deveria durar. Afinal, não é mais possível suportar a injustiça social, a desigualdade, a intolerância de gênero, de raça, de etnia...

Convivi com o amigo Brasilmar durante toda a minha vida acadêmica. Tornei-me amiga da sua família: Christiane, Joana, Emmanuelle, Lucas e César. Tivemos a oportunidade de conviver com mais intensidade nos últimos dois anos. Sempre me encontrava com ele, quando estava em Brasília, para participar das avaliaçóes do Conselho Nacional de Desenvolvimento Científico e Tecnológico (CNPq), sendo sua casa o meu refúgio. Nessas ocasióes, discutíamos política, comentávamos as nossas pesquisas, avaliávamos as nossas experiências acadêmicas e afetivas. Discorríamos sobre o nosso passado, presente e futuro. Eram os mais ricos momentos.

Durante os nossos recentes encontros, que se realizaram no período que se estendeu da reeleição de
Dilma até o início deste ano, ele mostrou a sua indignação, a sua revolta em relaçáo à tentativa de impeachment da nossa Presidenta da República. Consolávamo-nos.

Coincidentemente, Brasilmar faleceu no dia seguinte ao dia 17 de abril de 2016, quando a Câmara dos Deputados golpeou, de forma brutal, a democracia brasileira. Talvez ele não tenha assistido ao pesadelo que, doravante, se iniciava em nosso país por pura intuição. Ele já havia começado a se despedir deste mundo, a dormir profundamente, em paz, enquanto o Brasil entrava em uma das suas maiores tragédias.

Em todas as instituiçóes em que teve a oportunidade de trabalhar - em muitas delas assumindo funções de coordenação -, Brasilmar as engrandeceu. Assim foi no Programa de Pós-Graduação em Desenvolvimento Urbano da Universidade Federal de Pernambuco (MDU/ UFPE), na Superintendência do Desenvolvimento do Nordeste (SUDENE), nos Programas de Pós-graduação em Sociologia da Universidade Federal Fluminense (PPGS/UFF) e da Universidade de Brasília (PGSOL/ UnB), em comissóes de avaliação da Coordenação de Aperfeiçoamento de Pessoal de Nível Superior (Capes) e do CNPq.

Além de contribuir para a formação de muitos dos docentes dos aludidos programas, ele pensou com brilhantismo os problemas sociais do país. O seu pensamento pode ser apreciado em seus escritos, publicados em livros e periódicos.

Brasilmar foi um dos estudiosos das práticas socioespaciais de Brasília. Tornou-se um amante dessa cidade.

Eis, todavia, o mais importante: ele lutou pela sua vida e pela vida de seu entorno, até o horizonte infinito. Daí ser impossível esquecê-lo. Fica o registro de nossa gratidão, admiração e homenagem.

Norma Lacerda

Programa de Pós-graduação em Desenvolvimento Urbano/UFPE

DOI: http://dx.doi.org/10.22296/2317-1529.2016v18n1p19 